\title{
WATER QUALITY ASSESSMENT ALONG WITH POLLUTION SOURCES OF THE HALDA RIVER
}

\author{
MD. SHAFIQUL ISLAM ${ }^{1}$, ALI AKBAR $^{1}$, AYSHA AKHTAR ${ }^{1}$, \\ MD. MANZOORUL KIBRIA ${ }^{2}$ AND MD. SIMUL BHUYAN ${ }^{1 *}$ \\ ${ }^{1}$ Institute of Marine Sciences and Fisheries, University of Chittagong, Chittagong, Bangladesh \\ ${ }^{2}$ Department of Zoology, University of Chittagong, Chittagong, Bangladesh
}

\begin{abstract}
In the present study water quality assessment and land based sources of pollutants discharged into the Halda River through four major canals were investigated. The ranges of $\mathrm{pH}, \mathrm{DO}, \mathrm{BOD}, \mathrm{NO}_{3}-\mathrm{N}, \mathrm{PO}_{4}-\mathrm{P}$, chloride and total alkalinity of the collected samples varied from 7.1-8.8, 3.35-4.70 mg/L, 0.055-5.0 mg/L, 0.12-3.1 mg/L, 0.06-0.16 mg/L, 8.4-69.30 mg/L and 73-220 mg/L, respectively. $\mathrm{pH}$, DO, BOD showed significant changes at Mondakini Canal and Chengkhali Canal for monsoon, post-monsoon and winter $(\mathrm{p}<0.05)$ while chloride at Chengkali Canal for all seasons $(\mathrm{p} \leq 0.05)$. Moreover, $\mathrm{TA}, \mathrm{NO}_{3}-\mathrm{N}$ and $\mathrm{PO}_{4}-\mathrm{P}$ exhibited significant variation in the concentration at Mondakini Canal, Madari Canal and Chengkali Canal for three seasons $(\mathrm{p} \leq 0.05)$. River Pollution Index indicated that the water of river at Mondakini Canal, Madari Canal, Chengkhali Canal and Khondakia Canal varied from low to moderate pollution. According to the interviewers, the Halda River is being polluted due to industrial waste (53\%), sewage contamination $(20 \%)$, tobacco farming $(13 \%)$, rubber dam $(8 \%)$ and sand extraction $(6 \%)$. Therefore, necessary preventive measures should be taken in order to control the unwise and unauthorized discharge of harmful pollutants into the Halda River for the better management and conservation of natural resources.
\end{abstract}

Key words: Water Quality, Assessment, Pollution Sources, Parameters, Halda River

\section{Introduction}

Halda is the third main river of Chittagong district and has become the effecters of development providing fresh water supply, fish production, transportation and waste assimilation provision along with a wide array of recreation and tourism options (Kabir et al. 2013). The water of the Halda River is used for irrigation, agriculture, fish farming and livestock rearing, drinking and bathing. Halda River has a unique feature since it is the only natural breeding ground of major carps in Bangladesh (Kibria et al. 2009). Spawning area of this river is extended from Garduara to Maduna Ghat where a total of 1100 egg collectors and 2000 fisherman catch fish throughout the year (Islam 2009). Various species of fish namely Catla catla, Labeo rohita, Cirrhinus mrigala and other fresh water fish species chose to breed in the breeding ground of the Halda River (Tsai et al. 1981 and Patra and Azadi 1985).

River water uses for innumerable rural and urban communities and livestock, fish culture, recharge of ground water, control of floods etc. (Gurunathan and Shanmugam 2006). But the water quality is being degraded unceasingly due to haphazard industrialization

\footnotetext{
* Corresponding address: simulbhuyan@gmail.com
} 
(Manjare et al. 2010). Most of the industries discharged their insufficiently treated waste into the rivers or streams, which makes serious problem to aquatic flora and fauna (Kesalkar et al. 2012). Polluted water reduces fish production and availability of fish and also has an impact on other aquatic resources in the water (Mallick 2011). The dark color of the waste water exhibits the toxic effects on the biota and inhibits the photosynthetic activity by reducing the sunlight (Swamy 2011).

River pollution is a matter of concern all over the world (May et al. 2006, Noori et al. 2010 and Ouyang et al. 2006). Bangladesh is facing serious problems with water contaminations from different industries, domestic wastes and agrochemicals (Venugopal et al. 2009 and Islam et al. 2015a and b). Due to lack of waste management and sanitation facilities, raw and partially decomposed industrial and urban wastes and various hazardous chemicals substances from Raozan, Fatickchari, Hathazari and Biazid Thana find their way to the Halda River. Halda River is not focused well yet in terms of pollution status. Therefore, the present study was aimed to assess the water quality of the Halda River and to find out major pollution sources of the River.

\section{Materials and Methods}

Sampling Sites: The study was conducted in the Halda river which lies between $22^{\circ} 25^{\prime} 13^{\prime \prime}-22^{\circ} 48^{\prime} 51.37^{\prime \prime} \mathrm{N}$ and $91^{\circ} 45^{\prime} 00^{\prime \prime}-91^{\circ} 52^{\prime} 33^{\prime \prime} \mathrm{E}$ (Fig. 1). It is the sole natural breeding ground for carps (ruhi, katol, mrigal etc) due to the unique biochemical properties of its water. Industrial wastes, sewage discharge, tobacco farming, rubber dam and sand extraction are the main polluters of the river which are carried by canals. Four canals namely Mondakini (Station-1), Madari (Station-2), Chengkhali (Station-3) and Khondakia (Station-4) located from Nazirhat to Baluchara area along the Halda river bank were selected as the main discharge routes responsible for the Halda river pollution (Fig. 1).

Sample Collection and Preservation: After selection of sampling points, a total of 24 water samples was collected. Two water samples were collected for each seasons from the Mondakini, Madari, Cheng khali and Khondakia. Two liters of surface water sample were collected in the morning hours between 10 to $11 \mathrm{am}$, in polythene bottle regularly during every sampling. Immediately after collection, water sample were transferred to the laboratory of Institute of Marine Science and Fisheries, University of Chittagong. pH and DO were measured from studied sites during sampling of water. To find out the pollution sources; data were collected data using surveys, focus groups, key informant interviews and direct observations. Questionnaire survey was done for this study and interviewees were selected randomly (Henry 1990). The survey design was based on expert advice from local NGO staff and guidelines for identifying the major land based pollution sources of the Halda River (Kronen et al. 2007).

Sample Analysis: pH of water was determined by using Hanna pH meter. Chloride was measured by Volhard Method, alkalinity was determined by Titrimatric, DO was determined by using DO meter (Hanna DO meter, HI-9146), Bio-chemical oxygen demand (BOD) by modified Winkler method (1988). Moreover, $\mathrm{NO}_{3}-\mathrm{N}$ and $\mathrm{PO}_{4}-\mathrm{P}$ were measured following standard methods recommended by the APHA (2005) for waste water. 


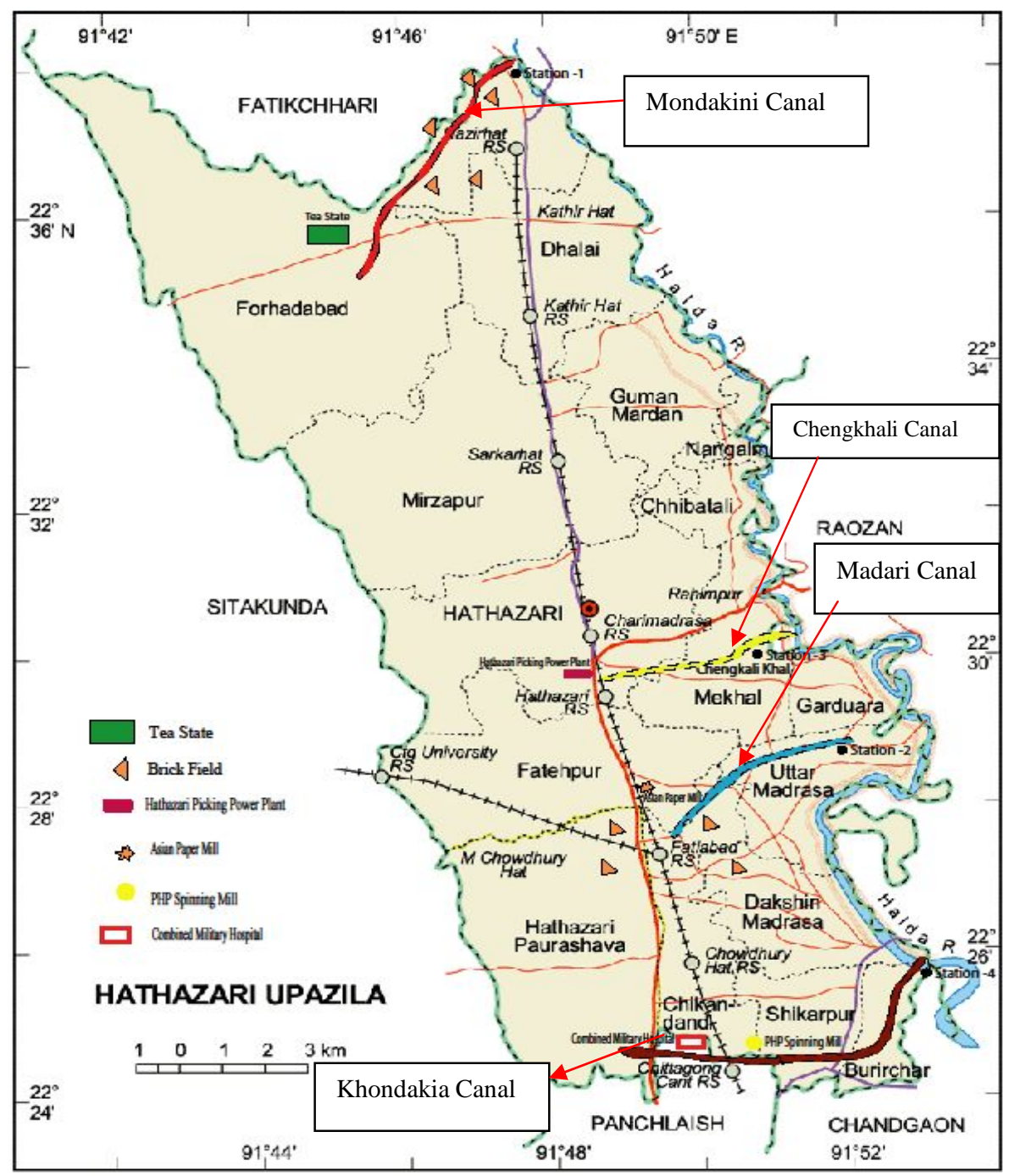

Fig. 1. Map showing sampling sites and pollution sources of the Halda River.

Statistical Analysis: The variations in water quality parameters of the studied canals measured in three different seasons were analyzed by using Two-Way ANOVA (SPSS v.22).

River Pollution Index (RPI): Each water quality variable used to determine RPI is changed to one of four index scores $\left(S_{i}=1,3,6\right.$, or 10). Particularly, RPI refers to the arithmetic average of these index scores with respect to the water quality (Table 1). 
RPI is computed using following equation (Liou et al. 2004).

$$
\mathrm{RPI}=1 / 4 \sum_{\mathrm{i}=1}^{4} \mathrm{Si}
$$

where $S_{i}$ represents the index scores and the RPI value ranges from 1 to 10 .

Table 1. River Pollution Index (RPI) Chart (Chen et al. 2012 and Liou et al. 2004).

\begin{tabular}{lllll}
\hline Items/ranks & Good & Less polluted & Moderately polluted & Highly polluted \\
\hline $\mathrm{DO}(\mathrm{mg} / \mathrm{L})$ & $>6.5$ & $4.6-6.5$ & $2.0-4.5$ & $<2.0$ \\
$\mathrm{BOD}_{5}(\mathrm{mg} / \mathrm{L})$ & $<3.5$ & $3.0-4.9$ & $5.0-15$ & $>15$ \\
$\mathrm{SS}(\mathrm{mg} / \mathrm{L})$ & $<2.0$ & $20-49$ & $50-100$ & $>100$ \\
$\mathrm{NH}_{3}-\mathrm{N}(\mathrm{mg} / \mathrm{L})$ & $<0.5$ & $0.5-0.9$ & $91.0-3.0$ & $>3.0$ \\
Index scores $(\mathrm{Si})$ & 1 & 3 & 6 & 10 \\
Sub-index & $<2$ & $2.0-3.0$ & $3.1-6.0$ & $>6.0$ \\
\hline
\end{tabular}

\section{Results and Discussion}

$\mathrm{pH}, \mathrm{DO}, \mathrm{BOD}$ showed significant changes in station-1 and station-3 for monsoon, postmonsoon and winter $(\mathrm{p}<0.05)$ while chloride at station-3 for all seasons $(\mathrm{p} \leq 0.05)$. Additionally, total alkalinity, $\mathrm{NO}_{3}-\mathrm{N}$ and $\mathrm{PO}_{4}-\mathrm{P}$ exhibited significant variation in the concentration in station- 1 , station- 2 and station- 3 for three seasons $(\mathrm{p} \leq 0.05)$.

There was no significant change in BOD level at different stations but significant shift was noticed in terms of total alkalinity at station-1 $(73 \mathrm{mg} / \mathrm{L})$ and station-2 $(210 \mathrm{mg} / \mathrm{L})$. This changing pattern followed by chloride at station-1 $(8.5 \mathrm{mg} / \mathrm{L})$ and station-2 $(65.6$ $\mathrm{mg} / \mathrm{L}$ ) during monsoon period (Table-3). In station-1, water $\mathrm{pH}$ was 7.1 followed by station-2 (8.7), station-3 (7.9) and station-4 (8.1) during post Monsoon. DO and BOD also varied according to stations but not significantly. Significant change was observed in case of chloride in different stations. Following monsoon and post Monsoon, water quality also changed in winter but not significantly. Significant variation was observed in terms of chloride (station-1 and station-4) and total alkalinity (station-1 and station-2). The concentration of DO and BOD found almost equal in station-3 and station- 4 which is shown in Table-3. The water quality variables of the Halda River compared with other rivers and with international standard shown in Table 2.

Dissolved Oxygen (DO): DO is an important ecological factor that decides environmental health of water bodies and support a well-balanced aquatic living organisms (Chang 2005 and George et al. 2012). The highest amount of DO recorded was $4.70 \mathrm{mg} / \mathrm{L}$ at Mondakini canal during winter. The lowest concentration recorded was $3.35 \mathrm{mg} / \mathrm{L}$ at Khondakia canal during monsoon (Table 3). More or less similar observations were also recorded by Jashim Uddin and Khan (1993), Islam and Khan (1993), Hossain (1998), Gasim et al. (2007) and Effendi et al. (2015). The low concentration of DO might be due to large amount of wastes discharged by canal and drainage system which utilized significant amount of DO for bio-chemical degradation. In the present investigation, the depletion of DO was found particularly due to the effluent discharged from Asian paper mill and Hathazari Picking power plant. 
Table 2. Water quality parameters of the Halda River comparing with international standard and other Bangladeshi study.

\begin{tabular}{l|l|l|l|l|l}
\hline Parameters & Present study & $\begin{array}{l}\text { Previous study } \\
\text { (Ahmed } \text { et al. } \\
2010)\end{array}$ & $\begin{array}{l}\text { Previous study } \\
\text { (Majid and Sharma } \\
1999)\end{array}$ & $\begin{array}{l}\text { WHO } \\
(1982)\end{array}$ & $\begin{array}{l}\text { ECR } \\
(1997)\end{array}$ \\
\hline $\mathrm{DO}(\mathrm{mg} / \mathrm{L})$ & $3.35-4.70$ & $3.02-9.90$ & $\mathrm{ND}$ & $4-6$ & 6 \\
$\mathrm{pH}$ & $7.1-8.8$ & $7.03-8.60$ & $5.65-7.34$ & $\mathrm{NYS}$ & $6.5-8.5$ \\
Chloride (mg/L) & $8.4-69.30$ & $2.41-73.50$ & $3.00-7.00$ & 600 & $150-600$ \\
Total Alkalinity & $73-220$ & $6.28-90.78$ & $22-72$ & - & - \\
$\mathrm{BOD}_{5}(\mathrm{mg} / \mathrm{L})$ & $0.055-5.0$ & $0.70-5.08$ & $\mathrm{ND}$ & 6 & 0.2 \\
$\mathrm{NO}_{3}-\mathrm{N}(\mathrm{mg} / \mathrm{L})$ & $0.12-3.1$ & 0.00 & $\mathrm{ND}$ & $\mathrm{NYS}$ & - \\
$\mathrm{PO}_{4}-\mathrm{P}(\mathrm{mg} / \mathrm{L})$ & $0.06-0.14$ & $0.73-4.28$ & $0.09-0.40$ & 0.8 & - \\
$\mathrm{BDL}^{-\mathrm{Bel}}$ & & & & \\
\hline
\end{tabular}

Table 3. Seasonal variation of water quality indicators of the Halda River.

\begin{tabular}{ll|l|l|l|l}
\hline Parameters & Season & Station-1 & Station-2 & Station-3 & Station-4 \\
\hline $\mathrm{DO}(\mathrm{mg} / \mathrm{L})$ & Monsoon & 3.9 & 3.5 & 3.45 & 3.35 \\
& Post-monsoon & 4.2 & 3.6 & 4.35 & 4.30 \\
$\mathrm{pH}$ & Winter & 4.7 & 4.1 & 4.31 & 4.28 \\
& Monsoon & 7.3 & 8.8 & 7.8 & 8.0 \\
& Post-monsoon & 7.1 & 8.7 & 7.9 & 8.1 \\
Chloride (mg/L) & Winter & 7.2 & 8.6 & 8.0 & 7.9 \\
& Monsoon & 8.5 & 65.60 & 56.30 & 60.15 \\
& Post-monsoon & 8.9 & 69.30 & 59.10 & 62.30 \\
Total Alkalinity & Winter & 8.4 & 59.20 & 52.60 & 61.15 \\
$(\mathrm{mg} / \mathrm{L})$ & Monsoon & 73 & 210 & 198 & 183 \\
& Post-monsoon & 77 & 218 & 207 & 192 \\
$\mathrm{BOD}_{5}(\mathrm{mg} / \mathrm{L})$ & Winter & 81 & 220 & 210 & 195 \\
& Monsoon & 0.28 & 0.057 & 0.055 & 0.056 \\
& Post-monsoon & 4.3 & 3.7 & 4.2 & 3.5 \\
$\mathrm{NO}_{3}-\mathrm{N}(\mathrm{mg} / \mathrm{L})$ & Winter & 4.1 & 2.5 & 5.0 & 3.4 \\
& Monsoon & 0.18 & 0.42 & 0.46 & 3.1 \\
& Post-monsoon & 0.15 & 0.37 & 0.39 & 0.27 \\
$\mathrm{PO}_{4}-\mathrm{P}(\mathrm{mg} / \mathrm{L})$ & Winter & 0.12 & 0.35 & 0.29 & 0.22 \\
& Monsoon & 0.08 & 0.14 & 0.14 & 0.13 \\
& Post-monsoon & 0.07 & 0.13 & 0.13 & 0.12 \\
& Winter & 0.06 & 0.12 & 0.12 & 0.1 \\
\hline
\end{tabular}

$p H: \mathrm{pH}$ is commonly known as the controlling variable in water since many properties, processes and reaction are $\mathrm{pH}$ dependent (Millero 1986). Alkaline water stimulates high primary production (Kumar and Prabhahar 2012). In the present study the value of $\mathrm{pH}$ showed slightly alkaline in nature at investigated areas which showed similarity with Roy (1955), Campbell (1978), Mahmood and Sarma et al. (1982), Bhuyian (1988) and Bhuyan and Bakar (2017). 
Chloride $(\mathrm{Cl})$ : Chlorides are not detrimental to public's health. Although the sodium part of $\mathrm{NaCl}$ salt connected to heart and kidney disease (Florescu et al. 2010). Sodium chloride $(\mathrm{NaCl})$ may render a salty taste at $250 \mathrm{mg} / \mathrm{L}$. Higher concentrations of dissolved salts in water compromise its use for domestic or agricultural purposes. Excessive amount of $\mathrm{Cl}^{-}$in inland water is usually considered as an index of pollution and can be provided across the hygienic and industrial waters (Florescu et al. 2010). In the present study the concentrations of chlorides recorded were between 8.4-69.30 mg/L. Maximum amount $(69.30 \mathrm{mg} / \mathrm{L})$ was found at station-2 during post-monsoon. Minimum value $(8.4$ $\mathrm{mg} / \mathrm{L}$ ) was recorded at station-1 during winter (Table 3).

Total Alkalinity: Total alkalinity was found to range between 73-220 mg/L (Table 3). The amount recorded in the present investigation was higher than Akter (2012) and Hossain (2004). Hoque et al. (2012) reported that the value of alkalinity in monsoon season was $50.4 \mathrm{mg} / \mathrm{L}$ and in winter season it was $146.5 \mathrm{mg} / \mathrm{L}$ in the Bansi River. The total alkalinity at Madari Canal was higher than that of the other stations during the period of investigation. These high values might be due to the highest alkaline effluent discharged by the Asian paper mill. More or less similar results were found by Hossain (1992) and Hossain (2004). Bhuyian (1979), Andrews (1984) and APHA (2005) stated that if the industrial effluents contain high concentration of chloride that could increase the chloride of water body where the effluent was being dumped.

Biochemical Oxygen Demand: BOD is the amount of oxygen used by microbes to decay carbon-based materials in water within five days period (APHA 2005). In the present study BOD varied between 0.055-5.0 mg/L (Table 3). According to Paul (1999), when river water contains BOD more than $10 \mathrm{mg} / \mathrm{L}$ it is considered to be moderately polluted and more than $20 \mathrm{mg} / \mathrm{L}$ to be highly polluted water but the present result was lower than these values. The acceptable value of BOD for fishing water is $\leq 6 \mathrm{ppm}$. Hossain (1988) and Hossain (1992) observed higher values of BOD in the disposal zone due to consumption of oxygen for the oxidation of large amount of wastes discharged from the municipal sewerage and surface runoff. These observations are in agreement with the present investigation.

Nitrate Nitrogen: The concentration of $\mathrm{NO}_{3}-\mathrm{N}$ was recorded between $0.12-3.1 \mathrm{mg} / \mathrm{L}$ (Table 3). The maximum values $3.1 \mathrm{mg} / \mathrm{L}$ was observed at Khondakia canal in the monsoon season and minimum value $0.12 \mathrm{mg} / \mathrm{L}$ at Mondakini canal in winter. The value fluctuated from monsoon to winter. Ahmed et al. (2010) found (BDL-0.87 mg/L) nitrate values in the Halda river and 0.00-1.63 mg/L from the Karnafuli river water.

Phosphate Phosphorus: The value of $\mathrm{PO}_{4}-\mathrm{P}$ was found to range between $0.06-0.14 \mathrm{mg} / \mathrm{L}$ (Table 3). The maximum value $0.14 \mathrm{mg} / \mathrm{L}$ was found at Madari canal and Chengkhali canal during monsoon. Majid and Sharma (1999) studied the Karnafuli River and found very low concentration of Phosphate. Ahmed et al. (2010) recorded 0.12-4.94 mg/L PO P- $^{-}$ P from the Karnafuli river water. Alam et al. (2007) worked on the river water quality and stated that the effluent and discharge area have a low concentration of phosphate.

River Pollution Index (RPI): In recent time, River pollution index (RPI) method is used concurrently by different organization like Taiwan EPA to assess the surface water 
quality. This method comprising with concentration level of four parameters namely DO, $\mathrm{BOD}, \mathrm{SS}$, and $\mathrm{NH}_{3}-\mathrm{N}$. Pollution status is calculated using four-state of each parameter.

In present study, the concentrations of $\mathrm{DO}$ and $\mathrm{BOD}_{5}$ were compared with concentrations of RPI table to weigh the status of particular water variables (Table 1). Average DO in the Mondakini Canal was found $3.9 \mathrm{mg} / \mathrm{L}$ during monsoon season that indicate the water is moderately polluted in comparison with RPI. The water of Madari canal contained 4.1 $\mathrm{mg} / \mathrm{L}$ DO that indicate the water is moderately polluted. Chengkhali Canal and Khondakia canal are also moderately polluted according to RPI Table.

During post-monsoon, average DO in the Mondakini Canal was recorded $4.2 \mathrm{mg} / \mathrm{L}$ which can be treated as moderately polluted zone according to RPI index while $4.35 \mathrm{mg} / \mathrm{L}$ and $4.30 \mathrm{mg} / \mathrm{L}$ DO were found from Chengkhali Canal and Khondakia canal that direct the area is moderately polluted. Where $3.6 \mathrm{mg} / \mathrm{L}$ was found from Madari canal area that also renders the area characterized with moderately polluted.

During winter the average DO concentration recorded was $4.7 \mathrm{mg} / \mathrm{L}$ at Mondakini canal, which designate less pollution in this area according to RPI table. Madari Canal, Chengkhali Canal and Khondakia canal are considered moderately polluted zone according to RPI index.

$\mathrm{BOD}_{5}$ were found between 3.0-4.9 mg/L for post-monsoon and winter at all the sampling sites indicating that the water of the river is less polluted according to (Table 3). During monsoon the water quality was found good. During winter the amount of $\mathrm{BOD}_{5}$ at Chengkhali canal was recorded $5.0 \mathrm{mg} / \mathrm{L}$ during winter season that indicate the water of the river canal is moderately polluted.

Sources of pollution: Structured questionnaire survey and direct observation were used to identify pollution sources of the river. According to the interviewers, the Halda River (the country's largest natural breeding ground for carps) is being polluted due to industrial waste $(53 \%)$, sewage contamination (20\%), tobacco farming (13\%), rubber dam (8\%) and sand extraction (6\%) (Fig. 2).

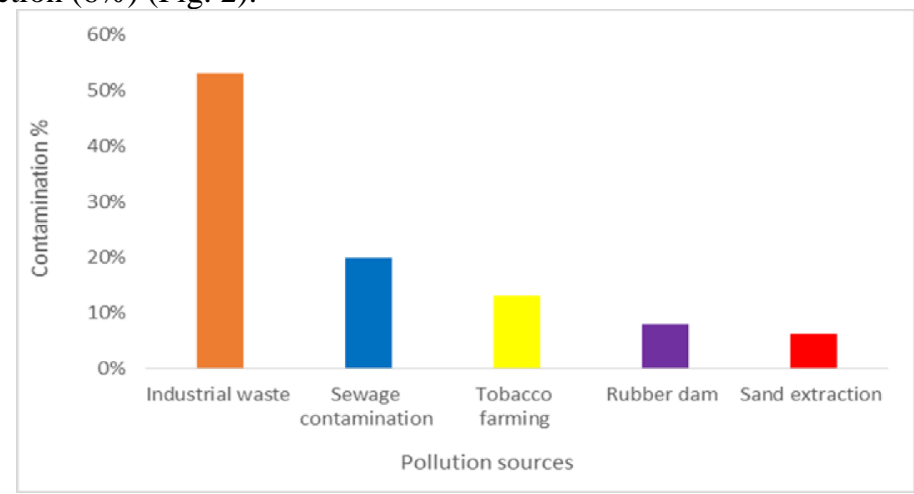

Fig. 2. Pollution contributors of the Halda River. 
The present study shows that the river Halda is being polluted from industrial and commercial sources at an alarming rate. Therefore, it is recommended that industrial and other effluents should be discharged into the river after proper treatment (ETP).

\section{References}

Ahmed, M.J., M.R. Haque, A. Ahsan, S. Siraj, M.H.R. Bhuiyan, S.C. Bhattacharjee, and S. Islam. 2010. Physicochemical Assessment of Surface and Groundwater Quality of the Greater Chittagong Region of Bangladesh, Pak. J. Anal. Environ. Chem. 11: 1 - 11 .

Akter, N. 2012. Water pollution in Karnafully River by Karnafully Paper Mill (KPM) and its effects on environment, M.Sc. Thesis, Institute of Marine Science and Fisheries, University of Chittagong, Bangladesh, 12: 24-33.

Alam, J.B., Z., Muyen, Islam, M.R., Islam, S., M. Mamun. 2007. Water quality parameters along rivers. Int. J. Environ. Sci. Tech. 4: 159-167.

Andrews, M.J. 1984. Thames Estuary: Pollution and Recovery, Thames Water Authority Metropolitan Pollution Control Northumberland House Mogden S. T. Works, Isleworth Middlesex TW7 7LP, England. p.195-225.

APHA (American Public Health Association), 2005. Standard Methods For the examination of water and waste water. $13^{\text {th }}$ edition, 1976, Broadway, New York- 10019.p-1200.

Bhuyian, A.M. 1979. Effect of industrial pollution on the biology of the Karnafully River. M. Phil Thesis, Department of Zoology, University of Chittagong, 3: 164.

Bhuyan, M.S. and M.A. Bakar. 2017. Assessment of water quality in Halda River (the Major carp breeding ground) of Bangladesh. Pollut. 3: 429-441.

Campbell, I.C. 1978. A Biological Investigation of an organically polluted urban stream In: Victoria Aust. J. Mar. Freshwater Res. 29: 275-291.

Chang, H. 2005. Spatial and temporal variations of water quality in the river and its tributaries, Seoul, Korea, 1993-2002. Water, Air, Soil Poll. 161: 267-284.

Chen, Y.C., H.C. Yeh and C. Wei. 2012. Estimation of river pollution index in a tidal stream using Kriging analysis. Int. J. Environ. Res. Public Heal. 9: 3085-3100.

Effendi, H., Romanto., Y. Wardiatno. 2015. Water quality status of Ciambulawung River, Banten Province, based on pollution index and NSF-WQI. Procedia Environ. Sci. 24: 228-237.

Florescu, D., R.E., Ionete, C., Sandru, A.Iordache, and M. Culea. 2010. The Influence of Pollution Monitoring Parameters in Characterizing the Surface Water Quality from Romania Southern Area. Rom. Journ. Phys. 56: 1001-1010.

Gasim, M.B., B.S., Ismail, E., Toriman, S.I. Mir and T.C. Chek. 2007. A Physico-chemical Assessment of the Bebar River, Pahang, Malaysia. Glo. J Environ. Res. 1: 7-11.

George, B., J.I.N. Kumar and N.R. Kumar. 2012. Study on the influence of hydro-chemical parameters on phytoplankton distribution along Tapi estuarine area of Gulf of Khambhat, India, Egyptian J Aqua. Res. 38: 157-170.

Gurunathan, A. and C.R. Shanmugam. 2006. Customary Rights and their Relevance in Modern Tank Management: Select Cases in Tamil Nadu, Paper prepared for the workshop entitled 'Water, Law and the Commons' organized in Delhi from 8 to 10 December 2006 by the International Environmental Law Research Centre (ILERC). p.1-17.

Henry, G.T. 1990. Practical Sampling. SAGE Publications, Newbury Park, CA, USA. 139p.

Hoque, M.M.M., S., Roy, M.N. Hoque and M.Z. Islam. 2012. Assessment of Some Water Quality Parameters of Bansi River in Monsoon and Winter Seasons. J. Environ. Sci. \& Natural Resour. 5: 53 -57.

Hossain, M. 2004. Sustainable management of the Bay of Bengal, large marine ecosystem (BOBLME). 
Hossain, M. 1998. A preliminary survey on the fisheries and socio-economic conditions of fishermen of the Old Brahmaputra River, MS Thesis, Department of Fisheries Management, BAU, Mymensingh. 21: 95.

Hossain, T. 1992. Study on the environmental impact assessment (ElA) of the effluent discharged by the Chittagong Urea Fertilizer Limited (CUFL) on the Karnafully River Estuary. Unpublished M.Sc. thesis. Marine Sciences.

Hossain, M.M. 1988. Some water quality characteristics of the karnafully river estuary. Mahasagar - Bull. National Inst. Oceanogra. 21: 183-188.

Islam, M.S., M.K. Ahmed, Habibullah-Al-Mamun, M. and M.F. Hoque. 2015a. Preliminary assessment of heavy metal contamination in surface sediments from a river in Bangladesh. Environ. Earth Sci. 73: 1837-1848.

Islam, M.S., M.K. M. Ahmed, M. Raknuzzaman, Habibullah-Al-Mamun and M.K. Islam. 2015b. Heavy metal pollution in surface water and sediment: a preliminary assessment of an urban river in a developing country. Ecolog. Indica. 48: 282-291.

Islam, M.T. 2009. Livelihood Condition of spawn carp fishing community at the western part of Halda River, Chittagong, Bangladesh. 11: 81.

Islam, M.M. and Y.S.A. Khan. 1993. Study on the influence of the effluent discharged by the KPM and $\mathrm{KRC}$ on the physiochemical parameters of the Karnafully River, Chittagong. M. Sc. Thesis, Institute of Marine Sciences, University of Chittagong. 79p.

Jashimuddin, S.M. and Y.S.A. Khan. 1993. Environmental Impact Assessment (EIA) of the municipal sewage discharge through majhirghat canal on the Karnafuli River water, Chittagong. M. Sc. Thesis, Institute of Marine Sciences, University of Chittagong. 85p.

Kabir, M.H., M.M. Kibria, M. Jashimuddin and M.M. Hossain. 2013. Economic Valuation of Tangible Resources from Halda-The Carp Spawning Unique River Located at Southern Part of Bangladesh, International Journal of Water Research, http://www.urpjournals.com.

Kesalkar, V.P., P.I. Khedikar and A.M. Sudame. 2012. Physico-chemical characteristics of wastewater from Paper Industry. Intern. J. of Engin. Res. Applica., 2: 137-143. www.ijera.com

Kibria, M.M., I. Farid and M. Ali. 2009. Halda Restoration Project: Peoples Expectation and Reality, A Review Report Based on the Peoples Opinion of the Project Area (In Bangla). Chittagong: Chattagram Nagorik Oddogh \& Actionaid Bangladesh. 67p.

Kronen, M., N., Stacey, P., Holland, F. Magron, and M. Power. 2007. Socioeconomic Fisheries Surveys in Pacific Islands: A Manual for the Collection of a Minimum Dataset. Secretariat of the Pacific Community (SPC), Noumea, New Caledonia, Available at: http://www2008.spc.int/DigitalLibrary/Doc/FAME/Manuals/ Kronen 07 SocioFish Surveys.pdf

Kumar, M.P. and C. Prabhahar. 2012. Physico-chemical parameters of river water: a review, Intern. J. of Pharma. Biolo. Arc. 3: 1304-1312.

Liou, S.M., S.L. Lo and S.H. Wang. 2004. A generalized water quality index for Taiwan. Environ. Monit. Assess. 96: 35-52.

Manjare, S.A., S.A. Vhanalakar and D.V. Muley. 2010. Analysis of water quality using physicochemical parameters Tamdalge tank in Kolhapur district, Maharashtra. Inter. J Advan. Biotech. Res. 1: 115-119.

May, A.M., E., Mutasem, D.S. Mark and N.L. John. 2006. Factors influencing development of management strategies for the Abou Ali River in Lebanon. Sci. Total Environ. 362: 1530 .

Mallick, S. 2011. River, Culture and Livelihoods: Water pollution and social around the river Bangshi, Bangladesh, Masters Diss. Future Generations Graduate School, Franklin, WV 2012. 116p.

Majid, M.A. and S.K. Sharma. 1999. A study of the water quality parameter of the Karnaphuly River, J. Ban. Chem. Soc. 12: 17-24. 
Mahmood, N. and A.M. Bhuyian. 1988. Some water quality characteristic of the Karnafully River estuary. Mahassagar Bull. Nati Inst. Sci. Ind. 22: 183-188.

Millero, F.J. 1986. The pH of estuarine waters, Limnol. \& Oceanogra. 31: 839-847.

Noori, R., M.S., Sabahi and A.R., Karbassi, A. Baghvand and H. Taati Zadeh. 2010. Multivariate statistical analysis of surface water quality based on correlations and variations in the data set. Desalination, 260: 129-136.

Ouyang, Y., P. Nkedi-Kizza, Q.T., Wu, D. Shinde and C.H. Huang. 2006. Assessment of seasonal variations in surface water quality. Water Res. 40: 3800-3810.

Paul, G. 1999. Environment and Pollution, Poribes Dushan (Ed), Dasgupta and Company Ltd, India. 2: 323

Patra, R.W.R. and M.A. Azadi. 1985. Hydrological conditions influencing the spawning of major carps in the H.R, Chittagong, Bangladesh.

Roy, H.K. 1955. Plankton ecology of the River Hoogly in Patna, West Bengal. Ecology. 36: 169175.

Sarma, V.V., G.R.K. Raju and T.B. Babu. 1982. Pollution Characteristics and water quality in the Visakhapatnam harbour. Mahasagar - Bull. National Inst. Oceanogra. 15: 15-22.

Swamy, N.K., P. Singh and I.P. Sarethy. 2011. Precipitation of phenols from paper industry wastewater using ferric chloride. Rasayan J Chemis. 4: 452-456.

Tsai, C., M.N. Islam, M.R. Karim and K.U.M.S. Rahman. 1981. Spawning of major carps in the lower Halda River, Bangladesh. Estuaries. 4: 127-138.

Venugopal, T., L. Giridharan and M. Jayaprakash. 2009. Characterization and Risk Assessment Studies of Bed Sedimentsof River Adyar-An Application of Speciation Study. Inter. J Environ. Res. 3: 581-598.

WHO, 1982. Examination of water for pollution control, a reference hand book" vol. 1, 2.

Winkler, L.W. 1988. The determination of dissolved oxygen in Water. Berlin. Deut. Chem. 21: 2845. 